\title{
Air Quality around Charcoal Making Kilns and the Potential Health Hazards
}

\author{
Omnya A. El-Batrawy
}

Environmental Sciences Department, Faculty of Science, Damietta University, Egypt

\author{
Received: 15 August 2019/ Accepted 22 Oct. 2019/ Publication date: 30 Oct. 2019
}

\begin{abstract}
Charcoal making kilns use highly inefficient technology and release significant amounts of air emissions. This study was designed to characterize major air pollutants from traditional kilns located in New Damietta City, Damietta, Egypt and to evaluate its potential health hazards. In-situ monitoring of $\mathrm{PM}_{10}, \mathrm{CO}, \mathrm{NO}_{2}, \mathrm{SO}_{2}$ and $\mathrm{NH}_{3}$ emissions were determined. Moreover, Heavy metals in $\mathrm{PM}_{10}(\mathrm{Co}$, $\mathrm{Cu}, \mathrm{Fe}, \mathrm{Pb}, \mathrm{Zn}, \mathrm{Ni}, \mathrm{Cd}$ ) were analyzed. Measurements were supplemented by a questionnaire on the possible health effects of charcoal production. Assessment of air quality monitoring data demonstrated that all emissions from charcoal kilns exceeded the prescribed limit as stipulated in EEAA. $\mathrm{CO}$ was found to be the most elevated level during emission followed by $\mathrm{PM}_{10}$. Among the heavy metals, the highest concentration was found to be $\mathrm{Pb}$ followed by Ni. The charcoal workers are exposed to high emissions generating a potential health risk. Pollution prevention strategies as well as public awareness might be sensible and valuable approaches to decrease hazardous air emissions around charcoal kilns areas.
\end{abstract}

Keywords: In-situ monitoring, particulates, gases, heavy metals, questionnaire.

\section{Introduction}

Charcoal has been extensively used for industry and private uses all over the world. Charcoal production is a danger to the environment as it utilizes ineffective carbonization processes (Njenga et al., 2013). While charcoal production is environmentally detrimental, its purchase and utilization are economically and culturally inherent in the daily life. Charcoal has advantages as fuel when contrasted to biomass as it has high heating value and simple storage (Antal and Grønli, 2003).

Charcoal is usually produced in kilns from wood pyrolyzing under high temperature in the deficiency of air (Tippayawong et al., 2010). Charcoal kilns can differ extraordinarily in structure and size, from earth mounds to brick kilns to large metal structures (Pennise et al., 2001). Earth mound or brick kilns are extensively utilized for charcoal production in Africa (Sparrevik et al., 2015). These charcoal kilns are not equipped with any control measures and, as a result of occupying the same position for many years, can cause local air pollution problems. Emissions vary noticeably over the run and may be discharged from a number of locations on the kiln (Smith et al., 1999).

Charcoal production leads to regional environmental pollution and loss of forest resources (Alem et al., 2010). Charcoal kilns discharge significant amounts of particulates, carbon monoxide, nitrogen dioxide and sulfur dioxide (Pennise et al., 2001). These emissions significantly alter the physical and chemical characteristics of the atmosphere (Crutzen and Andreae, 1990) and contribute to global warming (Chidumayo and Gumbo, 2013). Furthermore, emissions during charcoal production affect human health (Tzanakis et al., 2001; Orru et al., 2011; Abidin et al., 2014). Employees and general community in these areas have been exposed to emissions from these kilns. However, emissions from traditional kilns can be overcome by the development of new designs to improve performance of charcoal kilns (Syred et al., 2006; Adam, 2009; Bailis, 2009; Tippayawong et al., 2010, Sparrevik et al., 2015).

The charcoal production kilns in the developing world are hard to monitor as they frequently work over several days or even a long time for a single run (Smith et al., 1999). Few investigations have performed in-situ monitoring of gas emission from charcoal kilns (Smith et al., 1999; Pennise et al., 2001; Faé Gomes and Encarnação, 2012; Sparrevik et al., 2015). Furthermore, few reports have evaluated the association between occupational exposure to charcoal making emissions and respiratory disease (Tzanakis et al., 2001). Given the environmental and occupational impacts caused by charcoal production, this study was designed to characterize air emissions from conventional kilns

Corresponding Author: Omnya A. El-Batrawy, Associate Professor, Environmental Sciences Department, Faculty of Science, Damietta University, New Damietta City, Box 34517, Damietta, Egypt. E-mail: om_elbattrawy@du.edu.eg 
located in New Damietta City, Damietta, Egypt and to evaluate its potential health hazards. In-situ monitoring of $\mathrm{PM}_{10}, \mathrm{CO}, \mathrm{NO}_{2}, \mathrm{SO}_{2}$ and $\mathrm{NH}_{3}$ emissions were determined. Heavy metals in $\mathrm{PM}_{10}(\mathrm{Co}$, $\mathrm{Cu}, \mathrm{Fe}, \mathrm{Pb}, \mathrm{Zn}, \mathrm{Ni}, \mathrm{Cd}$ ) were analyzed. Moreover, the occurrence of possible health hazards during the charcoal production was reported.

\section{Materials and Methods}

\section{Study Area}

The study area of charcoal making kilns was in New Damietta City, Damietta, Egypt where earth mound kilns are used for charcoal production. Traditional earth kilns are used as they are cheap and require only labor to construct. The kilns have been operated by local staff. All charcoal was prepared in the dry season. Charcoal production involves cutting wood, burying it under a mound of earth and, finally igniting it underneath so that there is a limited air supply. The pyrolysis combustion process may take several days up to a few weeks. The extent of the combustion depends on the kiln size and the freshness and density of the wood. Kiln workers examine the amount and the color of the smoke, which specify the combustion stage. When the pyrolysis is complete, kiln workers manually remove the charcoal and store it nearby. Through operations, the same workers may perform all of the charcoal production tasks and suffer all of the accompanying hazards.

\section{Study Design}

Environmental measurements have been conducted within actual field conditions. Eight sampling stations (S1-S8) were chosen within the kilns area to characterize emissions from the charcoal making kilns. A total of 20 days of monitoring of particulate matter $\left(\mathrm{PM}_{10}\right)$, carbon monoxide $(\mathrm{CO})$, nitrogen dioxide $\left(\mathrm{NO}_{2}\right)$, sulfur dioxide $\left(\mathrm{SO}_{2}\right)$ and ammonia $\left(\mathrm{NH}_{3}\right)$ were carried out daily during summer season of 2018. The sampling arrangement configuration consisted of a gas collecting bottle, a $\mathrm{PM}_{10}$ sampling cassette holding a membrane filter, and personal pump. The pump provided a constant sampling flow rate of $3 \mathrm{~L} / \mathrm{min}$ for $2 \mathrm{hrs}$. The air was absorbed into the absorbing solutions for specific gases, and the transmission was estimated with a UV spectrometer. The levels of $\mathrm{CO}$ were determined by a portable monitor. Heavy metals in $\mathrm{PM}_{10}(\mathrm{Co}, \mathrm{Cu}, \mathrm{Fe}, \mathrm{Pb}, \mathrm{Zn}, \mathrm{Ni}, \mathrm{Cd})$ were analyzed. Measurements were supplemented by a questionnaire on the possible health effects of charcoal production.

\section{Experimental Analysis}

$\mathrm{PM}_{10}$ concentrations were estimated utilizing the filtration method (Harrison and Perry, 1986). Particles were collected on membrane filters (Whatman $47 \mathrm{~mm}$ with $2 \mu \mathrm{m}$ pores size). Filters were weighed in relative humidity and temperature control. Weighing technique is detailed elsewhere (ElBatrawy, 2010). $\mathrm{NO}_{2}$ was measured by sodium arsenite method at $\lambda=540 \mathrm{~nm} \mathrm{NH} 3$ gas was measured by Indophenol-Blue method at $\lambda=630 \mathrm{~nm}$ (Harrison and Perry, 1986). West and Gaeke method (Pararosaniline Method) was applied for determination of $\mathrm{SO}_{2}$ calorimetrically at $\lambda=548 \mathrm{~nm}$ (Lodge and Editor, 1998). The absorbance was measured by using of spectrophotometer (UNICO ${ }^{\mathrm{R}} 2000$ series). A portable Quest AQ5000 Pro monitor was used to monitor the concentration of CO. The heavy metals were extracted from the filter papers were digested with nitric acid and perchloric acid at a proportion of 3:2 utilizing a hot plate, as depicted by El-Batrawy et al. (2017). The extracted solution was filtered and washed by double distilled water and stored until examined using atomic absorption spectrophotometer (Model PinAAcle 500, PerkinElmer, USA).

\section{Potential Health Hazards}

Charcoal workers in the kilns study area were asked to complete a questionnaire recording the occurrence of possible health hazards during the charcoal production. The survey is supplemented with queries about occupational symptoms. Symptoms were considered as work related if workers reported them during the working period. They were asked for the occurrence of physical injury, sickness, dizziness, burns, eye irritation, cough/ wheezing, sinusitis and lung diseases. The daily exposure time to wood smoke in the kilns per day was also listed. The questionnaire also included queries about age, gender, time spent in working place, and smoking. Interest in the study was deliberate. All workers gave their informed endorsement. 


\section{Quality Control}

Data quality assurance procedures were enforced to ensure minimal contamination in sample handling and field work. All air samples were collected in duplicate. Field blanks were used and analyzed simultaneously with the exposed samples for quality control during the study. Flow rates were measured at the beginning and end of each sampling phase.

\section{Statistical Analysis}

The descriptive statistics were used to represent the data. The relationship among heavy metals in $\mathrm{PM}_{10}$ was assessed using Pearson's correlation coefficient. All analyses were performed using SPSS for Windows, v. 19.0 (SPSS, Inc., Chicago, IL).

\section{Results and Discussion}

\section{Emissions from Charcoal Making Kilns}

The mean concentrations of $\mathrm{PM}_{10}$ and gaseous emissions from charcoal kilns are shown in Table (1). The concentration of $\mathrm{PM}_{10}$ varied from $1127 \mu \mathrm{g} / \mathrm{m}^{3}$ (S7) to $3716 \mu \mathrm{g} / \mathrm{m}^{3}$ (S1) with an average of $2219.9 \mu \mathrm{g} / \mathrm{m}^{3}$ during the sampling period. Overall, $\mathrm{CO}$ was the prevailing gas emitted from charcoal kilns, with a concentration of $10650-15150 \mu \mathrm{g} / \mathrm{m}^{3}$. Other gases had lower average concentrations, with ranges of $434-709 \mu \mathrm{g} / \mathrm{m}^{3}$ for $\mathrm{NO}_{2}, 93-344 \mu \mathrm{g} / \mathrm{m}^{3}$ for $\mathrm{SO}_{2}$, and $30.49-126 \mu \mathrm{g} / \mathrm{m}^{3}$ for $\mathrm{NH}_{3}$.

Table 1: The mean concentrations of $\mathrm{PM}_{10}$ and gaseous emissions from charcoal kilns

\begin{tabular}{cccccc}
\hline Site & $\mathbf{P M}_{\mathbf{1 0}}$ & $\mathbf{N H}_{\mathbf{3}}$ & $\begin{array}{c}\text { Conc. }\left(\boldsymbol{\mu g} / \mathbf{m}^{\mathbf{3}}\right) \\
\mathbf{N O}_{\mathbf{2}}\end{array}$ & $\mathbf{S O}_{\mathbf{2}}$ & $\mathbf{C O}$ \\
\hline $\mathbf{S 1}$ & 3716 & 58.67 & 679 & 105 & 12220 \\
$\mathbf{S 2}$ & 1500 & 30.49 & 638 & 93 & 11050 \\
$\mathbf{S 3}$ & 1136 & 54.48 & 466 & 152 & 10650 \\
$\mathbf{S 4}$ & 1575 & 84.96 & 709 & 134 & 11720 \\
$\mathbf{S 5}$ & 3444 & 65.16 & 482 & 322 & 11560 \\
$\mathbf{S 6}$ & 2150 & 93.35 & 528 & 344 & 12610 \\
$\mathbf{S 7}$ & 1127 & 126 & 434 & 145 & 11750 \\
$\mathbf{S 8}$ & 3111 & 32 & 689 & 161 & 15150 \\
Average & 2219.9 & 68.1 & 578.1 & 182 & 12088.8 \\
\hline
\end{tabular}

The monitoring data showed that all emissions from charcoal kilns exceeded the prescribed limit as stipulated in EEAA (1995); $\left(150 \mu \mathrm{g} / \mathrm{m}^{3}\right.$ for $\left.24 \mathrm{hrs}\right)$ for $\mathrm{PM}_{10},\left(150 \mu \mathrm{g} / \mathrm{m}^{3}\right.$ for $\left.24 \mathrm{hrs}\right)$ for $\mathrm{NO}_{2}$ and $\mathrm{SO}_{2}$, and $\left(10 \mathrm{mg} / \mathrm{m}^{3}\right.$ for $8 \mathrm{hrs}$.) for CO. Emissions from charcoal kilns can be arranged according to the order: $\mathrm{CO}>\mathrm{PM}_{10}>\mathrm{NO}_{2}>\mathrm{SO}_{2}>\mathrm{NH}_{3}$ (Fig 1). It was found that, $\mathrm{CO}$ has the highest concentration followed by $\mathrm{PM}_{10}$. $\mathrm{CO}$ accounts for $80 \%$ of total emissions from charcoal kilns while $\mathrm{PM}_{10}$ accounts for $15 \%$ of emissions. Charcoal production is expected to contribute to the high levels of $\mathrm{PM}_{10}$ and gases as it is basically wood pyrolisis with the emission vented to the atmosphere.

$\mathrm{CO}$ was the highest concentration during emission due to low combustion temperature and deficient supply of oxygen during pyrolysis process. Besides, $\mathrm{CO}$ is emitted during the ignition of carbonic materials (Roy and Corscadden, 2012), the residence time of the burning gases was excessively short and fuel was not well mixed with air (Ozil et al., 2009). The high $\mathrm{PM}_{10}$ concentration indicates that charcoal kilns contributed substantially to particulate matter pollution levels in addition to common pollutant sources. Anthropogenic sources of $\mathrm{PM}_{10}$ include transportation, industry, fires, mechanical sources (Salam et al., 2008).

$\mathrm{NO}_{2}$ was seen as the second highest gas concentration during discharge. The amount of $\mathrm{NO}_{2}$ that can be discharged from charcoal kilns relates to the level of nitrogen as it is the major component of plant tissue. Anthropogenic outflows of $\mathrm{NO}_{2}$ in the area might be fundamentally because of burning procedures. During combustion $\mathrm{NH}_{3}$ were released and then oxidized to form $\mathrm{NO}$ that was oxidized later to $\mathrm{NO}_{2}$ (Winter et al., 1999). Moreover, high load of vehicular movement for charcoal transport were responsible for $\mathrm{SO}_{2}$ and $\mathrm{NO}_{2}$ emissions. Gasoline engine is the major source of $\mathrm{NO}_{2}$ 
while diesel vehicles are main sources for $\mathrm{SO}_{2}$ emissions (D'Angiola et al., 2010). A low concentration of $\mathrm{SO}_{2}$ may be because of the low sulfur content of the biomass.

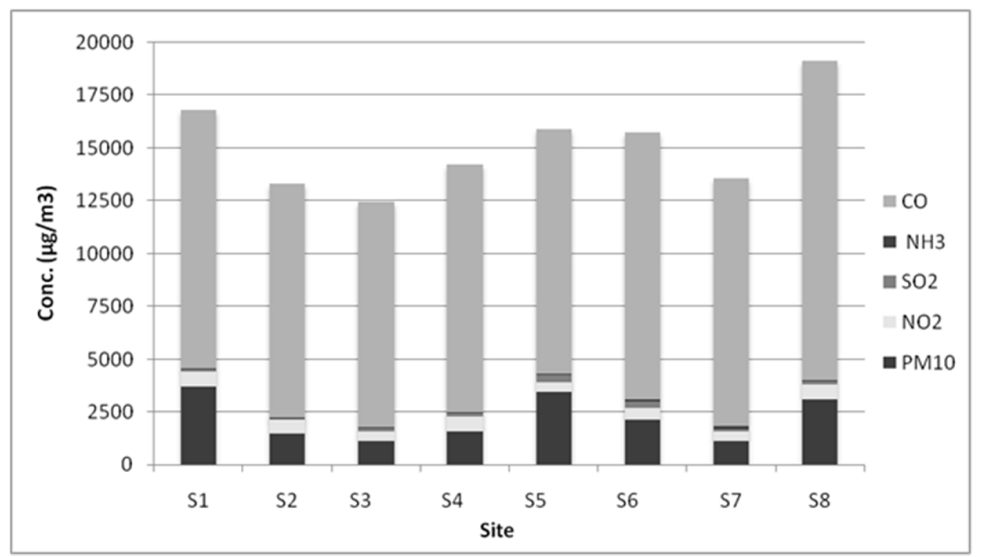

Fig. 1: Emissions of $\mathrm{PM}_{10}$ and gaseous emissions from charcoal kilns.

Other studies found high $\mathrm{CO}$ concentrations during tropical and peat land forest fires due to incomplete oxidation combustion (Andreae and Merlet 2001; Othman and Latif, 2013). High concentrations of CO emitted from open kilns have been identified in Zambia (Ellegard, 1994). Faé Gomes and Encarnação (2012) reported CO levels of 950 ppm near the ventilation holes of the traditional charcoal kiln.

Smith et al. (1999) characterized emissions from the most common charcoal kilns in the developing world and found that average emission factors, as $\mathrm{gm} / \mathrm{kg}$ charcoal formed, ranged from 110-340 for CO, 0.017-0.084 for $\mathrm{NO}_{2}$, and from 0.7- 4.2 for TSP. They found that simple charcoal kilns commonly used in developing countries convert only $43-47 \%$ of the energy content of wood into charcoal. Pennise et al. (2001) measured the emissions from charcoal kilns used in several developing countries, including typical earth-mound charcoal kilns during typical operating conditions. Emission factors were determined along with charcoal production efficiency. The conversion of wood to charcoal ranged from 37 to $69 \%$, according to kiln type. Emission factors, expressed as $\mathrm{gm} / \mathrm{kg}$ charcoal produced, ranged from $143-373$ for $\mathrm{CO}, 0.0054-0.13$ for $\mathrm{NO}_{\mathrm{x}}$, and 1341 for TSP.

\section{Heavy Metals Concentrations in $\mathbf{P M}_{10}$}

The mean concentrations of heavy metals $(\mathrm{Co}, \mathrm{Cu}, \mathrm{Fe}, \mathrm{Pb}, \mathrm{Zn}, \mathrm{Ni}, \mathrm{Cd})$ in $\mathrm{PM}_{10}$ from charcoal kilns are shown in Table 2. Among these heavy metals, the highest concentration was found to be $\mathrm{Pb}$. The concentration of $\mathrm{Pb}$ in $\mathrm{PM}_{10}$ emitted from charcoal kilns varied from $43.44 \mathrm{ppm}$ (S1) to 195.66 ppm (S6) with an average of $117 \mathrm{ppm}$ during the sampling period. The mean concentrations of other heavy metals in $\mathrm{PM}_{10} ; \mathrm{Co}, \mathrm{Cu}, \mathrm{Fe}, \mathrm{Zn}, \mathrm{Ni}$ and $\mathrm{Cd}$ were 11.59, 1.52, 2.76, 4.04, 45.74 and $11.28 \mathrm{ppm}$, respectively.

Table 2: The mean concentrations of heavy metals in $\mathrm{PM}_{10}$ from charcoal kilns

\begin{tabular}{cccccccc}
\hline Site & Co & Cu & Fe & Pb & Zn & Ni & Cd \\
\hline S1 & 1.27 & 0.49 & 0.98 & 43.44 & 1.63 & 3.85 & 3.24 \\
S2 & 16.82 & 0.03 & 0.52 & 73.70 & 16.78 & 13.33 & 7.84 \\
S3 & 3.44 & 0.16 & 1.56 & 75.87 & 0.22 & 25.76 & 1.24 \\
S4 & 15.13 & 3.32 & 3.60 & 190.76 & 0.37 & 69.37 & 4.19 \\
S5 & 16.87 & 1.68 & 1.75 & 111.58 & 0.90 & 79.92 & 28.27 \\
S6 & 5.70 & 2.20 & 4.40 & 195.66 & 7.34 & 17.32 & 14.60 \\
S7 & 15.50 & 0.72 & 7.04 & 194.74 & 0.98 & 96.02 & 5.60 \\
S8 & 18.00 & 3.56 & 2.26 & 50.26 & 4.06 & 60.40 & 25.26 \\
Average & 11.59 & 1.52 & 2.76 & 117.00 & 4.04 & 45.74 & 11.28 \\
\hline
\end{tabular}


The overall order of heavy metals concentration in $\mathrm{PM}_{10}$ from charcoal kilns is $\mathrm{Pb}>\mathrm{Ni}>\mathrm{Co}>$ $\mathrm{Cd}>\mathrm{Zn}>\mathrm{Fe}>\mathrm{Cu}$ (Fig 2). It is clear that lead was the dominated metal in charcoal kilns area. $\mathrm{Pb}$ has $60 \%$ contribution of $\mathrm{PM}_{10}$ followed by $\mathrm{Ni}(24 \%)$. The mean concentrations of $\mathrm{Pb}$ were exceeded the annual permissible limit $\left(1.0 \mu \mathrm{g} / \mathrm{m}^{3}\right)$ recommended by EEAA (1995). The high pollution of $\mathrm{Pb}$ metal may be associated with heavy traffic intensity to transport charcoal after production. $\mathrm{Pb}$ has been reported to be traffic related as ingredient of leaded gasoline (Weckwerth, 2001). Although leaded fuel is not in use, re-suspension of dust because of vehicle transportation increases $\mathrm{Pb}$ concentration in ambient air.

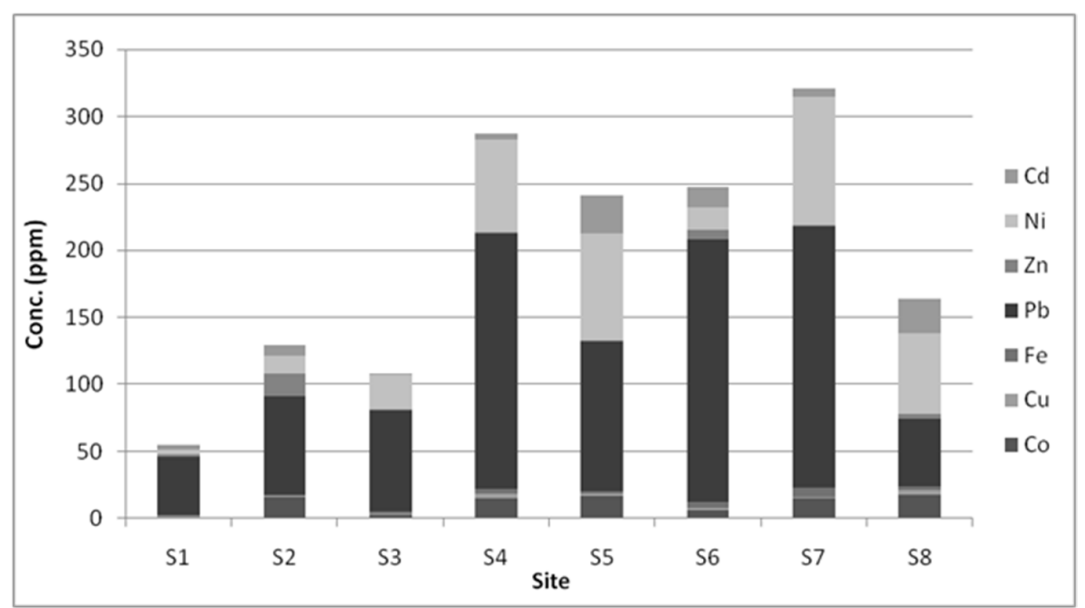

Fig. 2: Heavy metals concentration in $\mathrm{PM}_{10}$ from charcoal kilns

The occurrence of $\mathrm{Pb}, \mathrm{Ni}, \mathrm{Cu}, \mathrm{Cd}$, and $\mathrm{Zn}$ metals in the atmosphere are associated with the burning processes (Basha et al., 2010; Gummeneni et al., 2011; Shah et al., 2012; Yadav and Satsangi, 2013). Moreover, $\mathrm{Pb}$ and $\mathrm{Cd}$ have been reported to be traffic related as ingredients of leaded gasoline (Estrellan and Iino 2010). Cobalt is said to be sourced from both hydrocarbon sources and soil dust (Baptista et al., 2008). The presence of Fe might be because of its natural occurrence in the soil (Yongiie et al., 2009). When $\mathrm{Fe}$ is coupled with $\mathrm{Zn}$, pollution might be identified with incineration, fuel burning or natural source (Manalis et al., 2005).

A Pearson correlation matrix was performed to assess the relationship between heavy metals in $\mathrm{PM}_{10}$ (Table 3). The Pearson correlation coefficients for heavy metals concentrations in $\mathrm{PM}_{10}$ emissions from charcoal kilns verify that there were strong relationships between $\mathrm{Co}$ and $\mathrm{Cd}(\mathrm{r}=$ $0.518, \mathrm{p}<0.01)$, Co and $\mathrm{Ni}(\mathrm{r}=0.684, \mathrm{p}<0.01)$, Fe and $\mathrm{Pb}(\mathrm{r}=0.833, \mathrm{p}<0.01)$, Fe and $\mathrm{Ni}(\mathrm{r}=$ $0.604, \mathrm{p}<0.01)$ and $\mathrm{Cu}$ and $\mathrm{Cd}(\mathrm{r}=0.515, \mathrm{p}<0.01)$. These results suggest that these elements, which affect each other, were formed in burning processes. Moreover, the existence of a good correlation between $\mathrm{Ni}$ with $\mathrm{Cu}, \mathrm{Pb}$ and $\mathrm{Cd}$ may be due to the occurrence of these metals credited to other metal levels, especially during combustion process. A negative correlation for $\mathrm{Zn}$ with $\mathrm{Cu}, \mathrm{Fe}$, $\mathrm{Pb}$ and $\mathrm{Ni}$ proposes that higher concentrations of $\mathrm{Zn}$ lower the levels of other elements.

\section{Potential Health Hazards in the Workplace}

Many of the tasks concerned in charcoal production could be considered as potentially hazardous. Staff are usually exposed to smoke and covered by charcoal residue. A total of 20 workers ( 3 nonsmokers, 5 ex-smokers, and 12 smokers) participated in the study. The burning period is considered as the actual exposure time. The workers were exposed to the smoke of burning kilns for approximately 8 to $16 \mathrm{hr} / \mathrm{d}$ for 2 to 4 weeks. The extended work demands and long work shifts may improve the harmful impacts of the air emissions on the respiratory system. It was observed that workers do not use the respiratory protective equipment whenever during the burning process. 
Table 3: Correlation matrix for heavy metals concentrations in $\mathrm{PM}_{10}$

\begin{tabular}{|c|c|c|c|c|c|c|c|}
\hline & Co & $\mathrm{Cu}$ & $\mathbf{F e}$ & $\mathbf{P b}$ & $\mathrm{Zn}$ & $\mathbf{N i}$ & Cd \\
\hline Co & 1 & & & & & & \\
\hline $\mathrm{Cu}$ & 0.402 & 1 & & & & & \\
\hline $\mathbf{F e}$ & 0.173 & 0.228 & 1 & & & & \\
\hline $\mathbf{P b}$ & 0.160 & 0.281 & 0.833 & 1 & & & \\
\hline $\mathbf{Z n}$ & 0.226 & -0.246 & -0.317 & -0.170 & 1 & & \\
\hline $\mathbf{N i}$ & 0.684 & 0.403 & 0.604 & 0.465 & -0.489 & 1 & \\
\hline Cd & 0.518 & 0.515 & -0.095 & -0.119 & 0.037 & 0.351 & 1 \\
\hline
\end{tabular}

The reported potential health hazards by charcoal workers are represented in Fig (3). Physical injury is accounting for $80 \%$ among charcoal workers due to the use of primitive tools. The use of chainsaws and axes, combined with high temperatures, heavy loads and lack of safety training produce unsafe working conditions. Charcoal carriers subjected to physical injury due to repetitive movements, heavy loads and lack of equilibrium while climbing the truck. Lack of adequate treatment often limits contribution in activities due to illness and vulnerability to other hazards. A common response at kiln area includes coughing/ wheezing, sickness and eyes irritation, a sign of the tendency to develop diseases associated with the activity. Most of workers felt dizzy and nauseated. Almost $20 \%$ of workers were exposed to burns. In all, $50 \%$ of the workers suffer from sinusitis while $35 \%$ of them suffer from lung diseases. Workers of charcoal kilns experience injure to the lung function and other respiratory disorders (Tzanakis et al., 2001; Kato et al., 2005). Repeated contact could lead to chronic health problems.

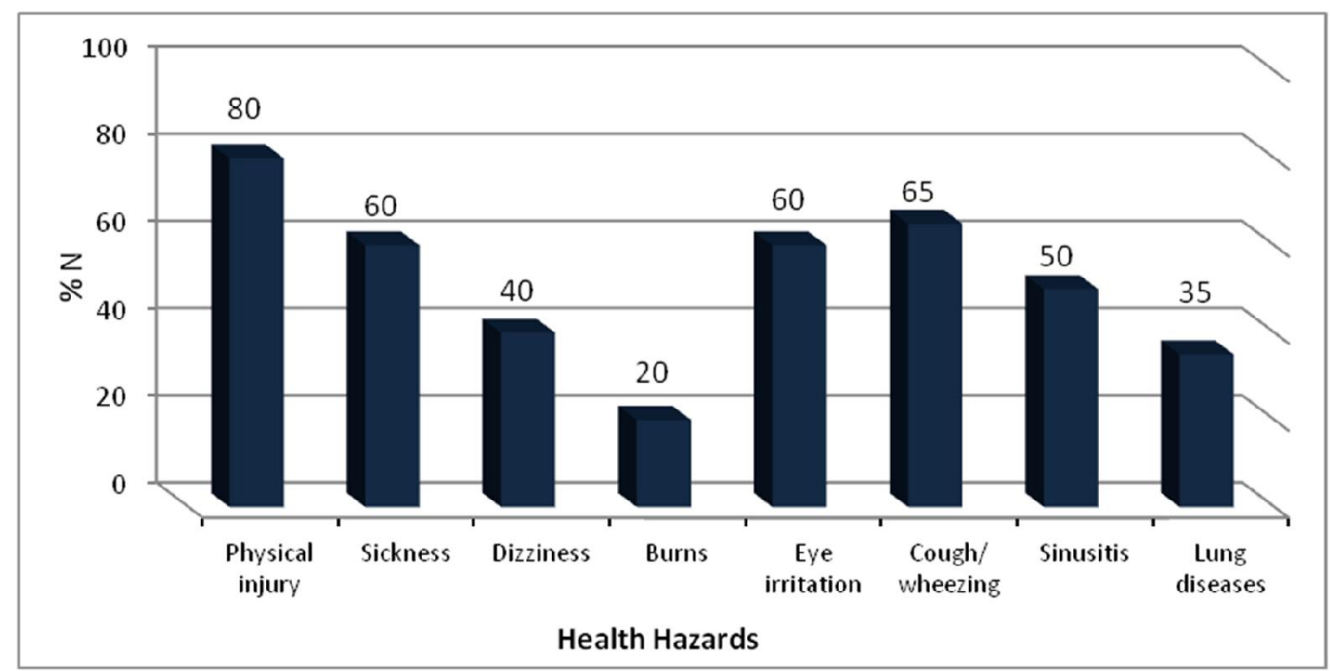

Fig. 3: Reported potential health hazards by charcoal workers $(\mathrm{N}=20)$.

The charcoal workers are exposed to high emissions from kilns (Table 1), generating a potential health risk. Wood smoke has been reported to enhance respiratory symptoms and to influence lung function even in low levels (Tzanakis et al., 2001). Chronic exposure to CO often produces symptoms such as headache, exhaustion, dizziness, and nausea (Salam et al., 2005). Moreover, Inhalation of CO in combination with particulates produces sore throat and irritation (Tzanakis et al., 2001). The exposure to $\mathrm{SO}_{2}$ has linked to breathlessness and wheezing and impaired lung function (Lambert, 1997). Exposure to $\mathrm{NO}_{2}$ may adversely affect lung function (Segala et al., 2004; Ciencewicki and Jaspers, 2007). Particulate matter may build up in different parts of the respiratory tract and cause mental retardation, attention deficit, hyperactivity, and cancer (Woodruff et al., 2004).

It was observed that children regularly help in the production phase. Although children normally employ in less physically intensive procedures, they can subject to severe health hazards. Inhalation of toxic gases in children is increasingly harmful to physical and mental development 
(Prockop and Chichkova, 2007). Also, the employment of children constrains children's time spent in school.

\section{Conclusion}

In-situ monitoring of $\mathrm{PM}_{10}, \mathrm{CO}, \mathrm{NO}_{2}, \mathrm{SO}_{2}$ and $\mathrm{NH}_{3}$ emissions from traditional kilns located in New Damietta City, Damietta, Egypt were determined. Moreover, Heavy metals in $\mathrm{PM}_{10}(\mathrm{Co}, \mathrm{Cu}, \mathrm{Fe}$, $\mathrm{Pb}, \mathrm{Zn}, \mathrm{Ni}, \mathrm{Cd})$ were analyzed. Evaluation of air quality monitoring data demonstrated that all emissions from charcoal kilns exceeded the prescribed limit as stipulated in EEAA (1995). Charcoal production is expected to contribute to the high levels of $\mathrm{PM}_{10}$ and gases as it is essentially wood pyrolisis. $\mathrm{CO}$ was found to be the highest concentration during emission followed by $\mathrm{PM}_{10}$. Among the heavy metals, the highest concentration was found to be $\mathrm{Pb}$ followed by $\mathrm{Ni}$. In the atmosphere, $\mathrm{Pb}$, $\mathrm{Ni}, \mathrm{Cu}, \mathrm{Cd}$, and $\mathrm{Zn}$ metals are all associated linked to some degree with the burning processes.

The charcoal workers work within close proximity to charcoal kilns and subjected to high emissions generating a potential health risk. Charcoal workers in the kilns study area were asked for the occurrence of physical injury, sickness, dizziness, burns, eye irritation, cough/ wheezing, sinusitis and lung diseases. Regular contact could prompt certain chronic health problems if the worker does not utilize respiratory protection equipment, which is fairly inconsistent. Traditional charcoal kilns use highly inefficient technology and release significant amounts of air emissions. Pollution prevention strategies as well as public awareness might be sensible and valuable approaches to decrease hazardous air emissions around charcoal kilns areas.

\section{References}

Abidin, E.Z., S. Semple, I. Rasdi, S.N.S. Ismail and J.G. Ayres, 2014. The relationship between air pollution and asthma in Malaysian school children. Air Qual Atmos Health, 7, 421-432.

Adam, J.C., 2009. Improved and more environmentally friendly charcoal production system using a low cost, retort-kiln (Eco-charcoal). Renewable Energy, 34, 1923-1925.

Alem, S., J. Duraisamy, E. Legesse, Y. Seboka and E. Mitik, 2010. Wood charcoal supply to Addis Ababa City and its effect on the environment. Energy \& Environment, 21(6): 601-609.

Andreae, M.O. and P. Merlet, 2001. Emission of trace Gases and Aerosols from Biomass Burning. Global Biogeochem. Cycles 15, 955-966.

Antal, M.J. and M. Grønli, 2003. The art, science, and technology of charcoal production. Ind. Eng. Chem. Res., 42, 1619-1640. http://dx.doi.org/10.1021/ie0207919.

Bailis, R., 2009. Modeling climate change mitigation from alternative methods of charcoal production in Kenya. Biomass Bioenergy, 33 (11): 1491-502.

Baptista, M.S., M. Teresa, S.D. Vasconcelos, J.P. Carbral and A.M.G. Pacheo, 2008. Copper, nickel, lead in lichens and tree bark transplants over different period of time. Environ Pollut, 151, 408413. https://doi. org/10.1016/j.envpol.2007.06.004.

Basha, S., J. Jhala, R. Thorat, S. Goel, R. Trivedi, K. Shah, G. Menon, P. Gaur, K.H. Mody and B. Jha, 2010. Assessment of heavy metal content in suspended particulate matter of coastal industrial town, Mithapur, Gujarat, India. Atmospheric Research, 97, 257-265.

Chidumayo, E.N. and D.J. Gumbo, 2013. The environmental impacts of charcoal production in tropical ecosystems of the world: A synthesis. Energy for Sustainable Development, 17, 86-94.

Ciencewicki, J. and I. Jaspers, 2007. Air pollution and respiratory viral infection. Inhalation Toxicology, 19, 1135-46.

Crutzen, P.J. and M.O. Andreae, 1990. Biomass burning in the tropics: Impact on atmospheric chemistry and biogeochemical cycles. Science, 250, 1669-1678.

D'Angiola, A., L.E. Dawidowski, D.R. Gómez and M. Osses, 2010. On-Road Traffic Emissions in a Megacity. Atmospheric Environment, 44, 483-493.

EEAA, 1995. Egyptian Environmental Affairs Agency. Law No. 4, 1994: Promulgating the environmental law and its executive regulation, Egypt.

El-Batrawy, O.A., 2010. Relationships between Personal, Indoor, and Outdoor $\mathrm{PM}_{10}$ in the Residential Environment in Damietta, Egypt. J. Am. Sci., 6, 1413- 22.

El-Batrawy, O.A., M.I. El-Gammal and M.A. Attia, 2017. Environmental Study on Atmospheric Suspended Particulate Matter and Heavy Metals in Sandoub Area, Al-Mansoura, Egypt. Scientific Journal for Damietta Faculty of Science, 7 (1): 65-73. 
Ellegard, A., 1994. Health effect of charcoal production from earth kilns in Chisamba Area, Zambia. Working paper. Energy environment and development series 34. Stockholm, Sweden: Stockholm Environment Institute, 1-16.

Estrellan, C.R. and F. Iino, 2010. Toxic emissions from open burning. Chemosphere, 80,193-207.

Faé Gomes, G.M. and F. Encarnação, 2012. The environmental impact on air quality and exposure to carbon monoxide from charcoal production in southern Brazil. Environmental Research, 116, 136-139.

Gummeneni, S., Y. Bin Yusup, M. Chavali and S.Z. Samadi, 2011. Source apportionment of particulate matter in the ambient air of Hyderabad City, India. Atmospheric Research, 101, $752-764$

Harrison, R.M. and R. Perry, 1986. Handbook of Air Pollution Analysis. $2^{\text {nd }}$ ed., Chapman and Hall, London, New York.

Kato, M., D. Demarini, A. Carvalho, M. Rego, A. Bonfim and D. Loomis, 2005. World at work: Charcoal producing industries in northeastern Brazil. Occupational and Environmental Medicine, 62, 128-132. https ://doi.org/10.1136/oem.2004.015172.

Lambert, W.E., 1997. Combustion pollution in indoor environments. In: Bardana E.J., Montanaro A (Eds.), Indoor Air Pollution and Health, Marcel Dekker, New York, pp. 83-103.

Lodge, J.P. and J.R. Editor, 1998. Methods of Air Sampling and Analysis, $3^{\text {rd }}$ ed., CRC Press LLC, Lewis Publishers, New York.

Manalis, N., G. Grivas, V. Protonotarios, A. Moutsatsou, C. Samara and A. Chaloulakou, 2005. Toxic metal content of particulate matter $\left(\mathrm{PM}_{10}\right)$, within the Greater Area of Athens. Chemosphere, $60,557-566$.

Njenga, M., N. Karanja, C. Munster, M. Iiyama, H. Neufeldt, J. Kithinji and R. Jamnadass, 2013. Charcoal production and strategies to enhance its sustainability in Ken ya. Development in Practice, 23 (3): 359-371. DOI: 10.1080/09614524.2013.780529.

Orru, H., M. Maasikmets, T. Lai, T. Tamm, M. Kaasik, V. Kimmel, K. Orru, E. Merisalu and B. Forsberg 2011. Health impacts of particulate matter in five major Estonian towns: main sources of exposure and local differences. Air Qual Atmos Health, 4, 247-258.

Othman, M. and M.T. Latif, 2013. Dust and Gas Emissions from Small-Scale Peat Combustion. Aerosol and Air Quality Research, 13, 1045-1059.

Ozil, F., V. Tschamber, F. Haas and G.Trouve, 2009. Efficiency of Catalytic Processes for the Reduction of CO and VOC Emissions from Wood Combustion in Domestic Fireplaces. Fuel Process. Technol., 90, 1053-1061.

Pennise, D.M., K.R. Smith, J.P. Kithinji, M.E. Rezende, T.J. Raad, J. Zghang and C. Fan, 2001. Emissions of greenhouse gases and other airborne pollutants from charcoal making in Kenya and Brazil. Journal of Geophysical Research, 106 (D20): 24143-155.

Prockop, L. and R. Chichkova, 2007. Carbon monoxide intoxication: An updated review. Journal of the Neurological Sciences, 262 (1): 122-130.

Roy, M.M. and K.W. Corscadden, 2012. An Experimental Study of Combustion and Emissions of Biomass Briquettes in a Domestic Wood Stove. Appl. Energy, 99, 206-212.

Salam, A., T. Hossain, M.N. Siddique and A.M. Alam, 2008. Characteristics of atmospheric trace gases, particulate matter, and heavy metal pollution in Dhaka, Bangladesh. Air Qual Atmos Health, 1, 101-9.

Salam, M.T., J. Millstein, Y.F. Li, F.W. Lurmann, H.G. Margolis and F.D. Gilliland, 2005. Birth outcomes and prenatal exposure to ozone, carbon monoxide, and particulate matter: Results from the children's health study. Environmental Health Perspectives, 113(11): 1638-1644.

Segala, C., D. Poizeau, F. Neukirch, M. Aubier, J. Samson and P. Gehanno, 2004. Air pollution, passive smoking and respiratory symptoms in adults. Arch Environ Health, 59, 669-76.

Shah, M.H., N. Shaheen and R. Nazir, 2012. Atmospheric Pollution Research Assessment of the Trace Elements Level in Urban Atmospheric Particulate Matter and Source Apportionment in Islamabad, Pakistan. Atmos. Pollut. Res., 3, 39-45.

Smith, K.R., D.M. Pennise, P. Khummongkol, V. Chaiwong, K. Ritgeen, J. Zhang, W. Panyathanya, R.A. Rasmussen and M.A.K. Khalil, 1999. In: Agency USEP, editor. Greenhouse gases from small-scale combustion devices in developing countries. Phase III: charcoal-making kilns in 
Thailand; EPA-600/R-99-109. United States Environmental Protection Agency Research and Development, Washington, DC.

Sparrevik, M., C. Adam, V. Martinsen, G. Jubaedah, Cornelissen, 2015. Emissions of gases and particles from charcoal/ biochar production in rural areas using medium sized traditional and improved "retort" kilns. Biomass and Bioenergy, 72, 65-73.

Syred, C., A.J. Griffiths, N. Syred, D. Beedie and D. James, 2006. A clean, efficient system for producing charcoal, heat and power (CHaP). Fuel, 85, 1566-1578.

Tippayawong, N., N. Saengow, E. Chaiya and N. Srisang, 2010. Production of charcoal from woods and bamboo in a small natural draft carbonizer, International Journal of Energy and Environment (IJEE), 1 (5): 911-918.

Tzanakis, N., K. Kallergis, D. Bouros, M. Samiou and N. Siafakas, 2001. Short-term effects of wood smoke exposure on the respiratory system among charcoal production workers. Chest, 119, 1260-1265. https ://doi.org/10.1378/chest .119.4.1260.

Weckwerth, G., 2001. Verification of traffic emitted aerosol components in the ambient air of Cologne (Germany). Atmospheric Environment, 35, 5525-5536.

Winter, F., C. Wartha and H. Hofbauer, 1999. NO and $\mathrm{N}_{2} \mathrm{O}$ Formation during the Combustion of Wood, Straw, Malt Waste and Peat. Bioresour. Technol., 70, 39-49.

Woodruff, T., D. Axelrad, A. Kyle, O. Nweke, G. Miller and B. Hurley, 2004. Trends in environmentally related childhood illnesses. Pediatrics, 113, 1133-1140.

Yadav, S. and P.G. Satsangi, 2013. Characterization of particulate matter and its related metal toxicity in an urban location in South West India. Environmental Monitoring and Assessment, 185, 7365-7379.

Yongjie, Y., W. Yuesi, W. Tianxue, L. Wei, Z. Ya'nan and L. Liang, 2009. Elemental composition of $\mathrm{PM}_{2.5}$ and $\mathrm{PM}_{10}$ at Mount Gongga in China during 2006. Atmos Res, 93, 801-810. https://doi.org/10. 1016/j.atmosres.2009.03.014. 